\title{
The Digital Economy of BRICS: Prospects for Multilateral Cooperation ${ }^{1}$
}

\section{A. Ignatov}

Alexander Ignatov, Researcher, Centre for International Institutions Research, Russian Presidential Academy of National Economy and Public Administration; 11 Prechistenskaya naberezhnaya, Moscow, 119034, Russian Federation; E-mail: ignatov-aa@ranepa.ru

\begin{abstract}
The growth of the digital economy has become the most significant trend in global development. The digital economy creates new impetuses for economic growth, but at the same time it deepens global inequality and impacts the growth of countries of the global South. The role of global governance institutions such as the BRICS grouping of Brazil, Russia, India, China and South Africa - the main representative of developing countries in global governance in the promotion of digital growth has not yet been fully explored. There is also some ambiguity concerning the development level of the digital economy in particular countries. In the context of Russia's third BRICS presidency in 2020, issues of digital development in BRICS have become particularly relevant. The author analyzes current indicators of digital development in the BRICS countries, drawing on several existing methodologies, ratings, and decisions made by BRICS on issues of digital growth and levels of compliance, and makes recommendations for the further development of BRICS' digital agenda.

According to data provided by the Organisation for Economic Co-operation and Development (OECD), the International Telecommunication Union (ITU), the World Bank, the World Economic Forum (WEF), the European Union (EU) and the International Development Institute (IDI), the BRICS countries differ in terms of the maturity of their digital economies. They are characterized by a relatively low quality and affordability of digital infrastructure; additionally, the penetration of information and communications technology (ICT) into business and daily activities in BRICS countries lags behind the world leaders, and data on the quality and efficiency of regulatory and innovative frameworks in the BRICS countries is insufficient. However, decisions made by BRICS on matters of digital growth are followed with a high-average level of compliance. Thus, recommendations for the further development of BRICS' digital agenda are strategic in nature. The author defines three promising areas of cooperation on digital matters during Russia's 2020 BRICS presidency: facilitation of dialog and exchange of best practices supporting digital growth; development of a common BRICS standard offor the production of digital goods and services and; promotion of a common BRICS position on cybersecurity issues.
\end{abstract}

Key words: BRICS; digital economy; development; global governance

For citation: Ignatov A. (2020) The Digital Economy of BRICS: Prospects for Multilateral Cooperation. International Organisations Research Journal, vol. 15, no 1, pp. 31-62 (in English). DOI: DOI: 10.17323/19967845-2020-01-02.

The emergence and rapid proliferation of the digital economy is one of the most significant trends of global development in recent decades. The digital economy and related features such

${ }^{1}$ The editorial board received the article in August 2019.

The study was carried out as part of the research work of the state task of the RANEPA "Analysis of the possibilities for coordinating the positions of the BRICS countries on key tasks of the international community" (2020). 
as digitization (the use of data and digital technologies as well as interconnections that result in new activities, or changes to existing ones [OECD, 2019a, p. 7]), have a significant impact on the global economy, national economies and daily life. The digital economy has accomplished much recently. In 2015, the total value of information and communications technology (ICT)related trade has surpassed $\$ 2$ trillion, while production of ICT goods creates about $6.5 \%$ of the global GDP. In the same year, exports of ICT services grew by 40\% (compared with 2010) and more than 100 million jobs were created due to the spread of ICTs [UNCTAD, 2017a].

However, development of the digital economy creates both opportunities and challenges. Among them is the growing digital divide [OECD, 2001] between developed and developing countries characterized by low-levels of penetration of the digital technologies (Fig. 1) that results in de-industrialization of developing countries and increased vulnerabilities [Bukht, Heeks, 2018, p. 146].

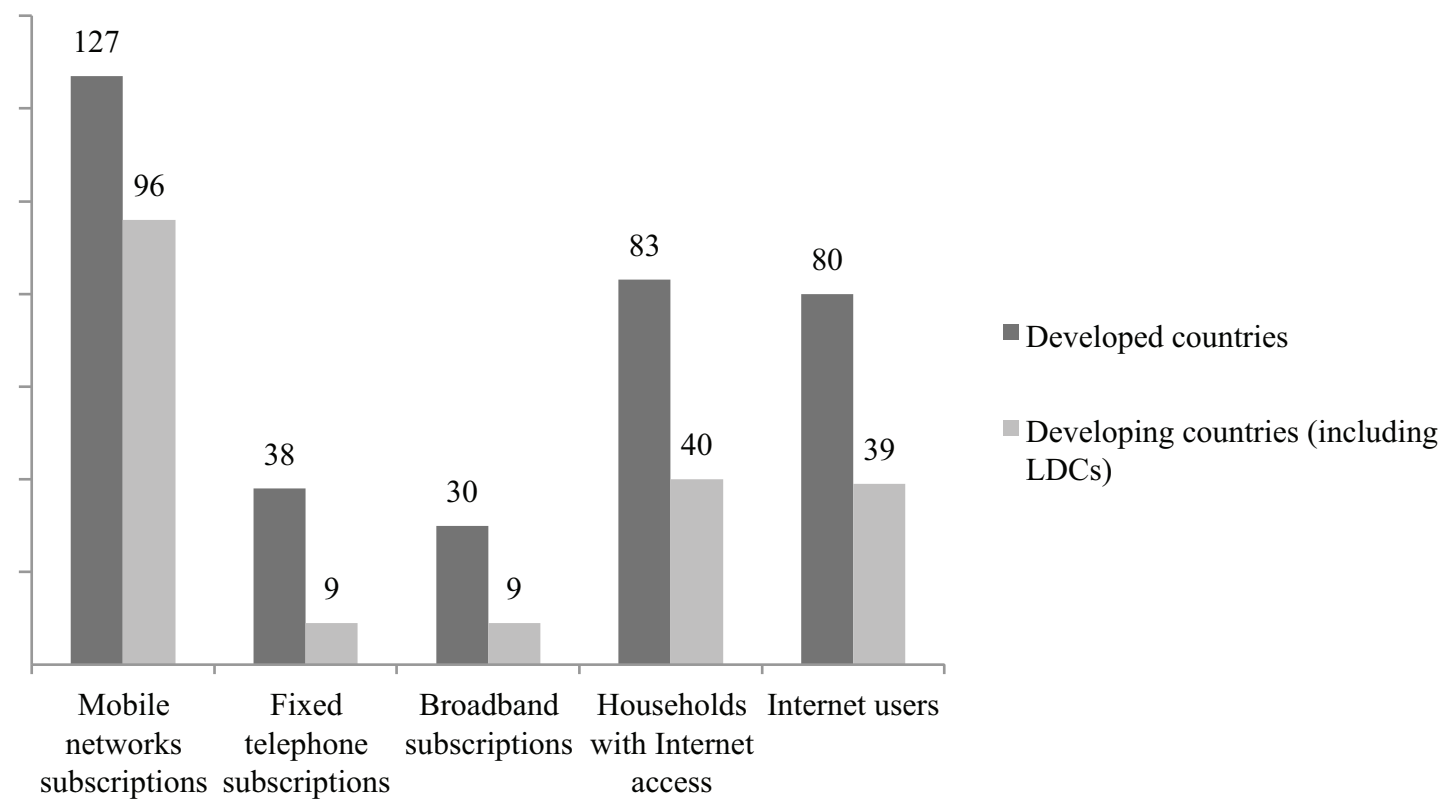

Fig. 1. ICT Penetration in Developed and Developing Countries

Source: [ITU, 2017].

Digitization is closely associated with a growing income divide both in developed and developing countries [European Commission, 2019, p. 16; Zhang, Chen, 2019, p. 18]. It is also linked to growing protectionism in trade in the absence of a universal standard of production for digital goods and services [United States Trade Representative, 2018], and to new threats emerging from cyberspace [Hansen, Nissenbaum, 2009, p. 1161].

The challenges of the digital age attract much attention due to the unexplored nature of the digital economy. A unified mechanism for the measurement and assessment of the digital economy has not yet been introduced, and the lack of reliable statistics on digital development remains a problem. Recent research is generally devoted to issues related to digital growth in high-income countries of the global North rather than of the global South, which is experiencing trouble incorporating ICTs into governance, business activities and labour markets [Bukht, Heeks, 2018, p. 146]. The role of global governance institutions such as the BRICS grouping of 
Brazil, Russia, India, China and South Africa - the main representative of developing countries in global governance - in the promotion of digital growth has not yet been fully explored.

Issues related to digital growth are the most recent additions to the BRICS agenda and the BRICS countries themselves are at different stages of digital development. Deep analysis of the national priorities of the partner countries in the digital sphere is the matter of highest priority for the presidency of Russia in BRICS in 2020. Thus, the goal of this article is to provide recommendations for the promotion of Russia's priorities in the digital sphere during its presidency, based on analysis of recent data on digital development in the BRICS economies in accordance with internationally recognized methodologies and toolkits, as well as decisions taken by BRICS on digital matters.

\section{Digital Economy: Definition and Assessment}

Despite the growing impact of the digital economy, there is, as of yet, no agreed upon definition of this concept. Don Tapscott was one of the pioneers, among many others, who tried to define the digital economy. In his book, The Digital Economy: Promise and Peril in the Age of Networked Intelligence, Tapscott referred to this notion as something that is "based on information of all kinds... transmitted by means of networked technologies" [Tapscott, 2015, p. 16]. In recent decades, more definitions by the United Nations Conference on Trade and Development (UNCTAD), the Organisation for Economic Co-operation and Development (OECD), the World Bank Group, the International Monetary Fund (IMF) and other institutions were introduced (Table 1).

All the above-mentioned definitions, including the definition by Don Tapscott, take the Internet and ICTs as the core of the digital economy regardless of historical and technological context. Some of these definitions also consider the creation of ICTs and ICT-related services as integral parts of the digital economy.

"The near ubiquitous diffusion of information and communication technologies has led to their convergence with other technologies such as biotechnologies and nanotechnologies" [OECD, 2014, p. 18], which complicates not only the conceptualization of the digital economy, but also its assessment. Some experts maintain the connection between the emergence of the new "productivity paradox" economic slowdown in the leading economies, and limitation of currently accepted economic indicators, namely the value of gross national product (GNP), for usage in assessment of the digital economy [Watanabe et al., 2018, p. 226]. Lack of a conventional approach leads to significant divergence in assessments - thus, the digital economy in China produces anything from $6 \%$ to $30 \%$ of the country's gross domestic product (GDP) depending on the definition used [Zhang, Chen, 2019, p. 4].

Several methodologies form the basis for international ratings of the development of the digital economy. These methodologies can be divided into three groups: first, toolkits built to measure specific parameters of the digital economy; second, ratings based mostly on technical parameters and; third, ratings based on a mixed set of parameters including both statistics and estimations. The OECD Toolkit for Measuring the Digital Economy and the OECD Going Digital Toolkit are valuable sources of essential information on digital growth that can also serve as guidelines for national policy planning. These toolkits are not designed for further ranking of countries in terms of the maturity of their digital economies. The second group, including the ICT Development Index and the Digital Adoption Index, is the most suitable for assessment of the quality of a country's digital infrastructure due to the parameters used, while the third group, consisting of the Networked Readiness Index, the European Union's International Digital Economy and Society Index (I-DESI), and the Institute for Management 
Table1. Definitions of the Digital Economy and Relevant Concepts

\begin{tabular}{|c|c|c|}
\hline Source & $\begin{array}{c}\text { Definition of the "Digital Economy" } \\
\text { and/or a Relevant Concept }\end{array}$ & $\begin{array}{l}\text { Definitions of Concepts Related } \\
\text { to the Development of the Digital Economy }\end{array}$ \\
\hline UNCTAD & $\begin{array}{l}\text { "The digital economy - the application of } \\
\text { internet-based digital technologies to the } \\
\text { production and trade of goods and services - } \\
\text {..." [UNCTAD, 2017b, p. 156] }\end{array}$ & - \\
\hline WEF & $\begin{array}{l}\text { The Internet economy is "purchasing power } \\
\text { in the hands of people using the Internet" } \\
\text { [Dutta, Mia, 2011, p. 34] }\end{array}$ & $\begin{array}{l}\text { Digitization: "the mass adoption of } \\
\text { connected digital services by consumers, } \\
\text { enterprises, and governments" [Bilbao- } \\
\text { Osorio, Dutta, Lanvin, 2013, p. vii] }\end{array}$ \\
\hline OECD & $\begin{array}{l}\text { The Internet economy is "the full range } \\
\text { of our economic, social and cultural } \\
\text { activities supported by the Internet and } \\
\text { related information and communications } \\
\text { technologies (ICT)" [OECD, 2008, p. 4]. } \\
\text { The Internet economy is "the value of all } \\
\text { economic activities that are undertaken on } \\
\text { or supported by the Internet" [OECD, 2013, } \\
\text { p. 6] }\end{array}$ & $\begin{array}{l}\text { Digital divide: "different levels of access } \\
\text { and use of information and communication } \\
\text { technologies (ICTs) and, more specifically, } \\
\text { to the gaps in access and use of Internet- } \\
\text { based digital services" [OECD, 2018, p. 11]. } \\
\text { Digitization: "the use of data and digital } \\
\text { technologies as well as interconnection } \\
\text { that results in new, or changes to existing, } \\
\text { activities" [OECD, 2019a, p. 7]. } \\
\text { Digital infrastructure: "efficient, } \\
\text { reliable and widely accessible broadband } \\
\text { communication networks and services, } \\
\text { data, software, and hardware, are the } \\
\text { foundations on which the digital economy } \\
\text { is based" [OECD, 2017, p. 28] }\end{array}$ \\
\hline IMF & $\begin{array}{l}\text { "The 'digital economy' is sometimes defined_ } \\
\text { narrowly as online platforms, and activities } \\
\text { that owe their existence to such platforms, } \\
\text { yet, in a broad_sense, all activities that use } \\
\text { digitized data are part of the digital economy: } \\
\text { in modern economies, the entire economy" } \\
\text { [IMF, 2018, p. 7] }\end{array}$ & $\begin{array}{l}\text { Digitalization: "the incorporation of data } \\
\text { and the Internet into production processes } \\
\text { and products, new forms of } \\
\text { household and government consumption, } \\
\text { fixed-capital formation, cross-border flows, } \\
\text { and finance" [IMF, 2018, p. 6]. } \\
\\
\text { Digital sector: "comprising the producers at } \\
\text { the core of digitalization: online platforms, } \\
\text { platform-enabled services, and suppliers of } \\
\text { ICT goods and services" [IMF, 2018, p. 7] }\end{array}$ \\
\hline G20 & $\begin{array}{l}\text { "The digital economy refers to a broad } \\
\text { range of economic activities that includes } \\
\text { using digitized information and knowledge } \\
\text { as the key factor of production, modern } \\
\text { information networks as the important } \\
\text { activity space, and the effective use } \\
\text { of Information and Communication } \\
\text { Technology (ICT) as an important driver } \\
\text { for efficiency-enhancing and economic } \\
\text { structural optimization" [G20, 2016] }\end{array}$ & - \\
\hline
\end{tabular}




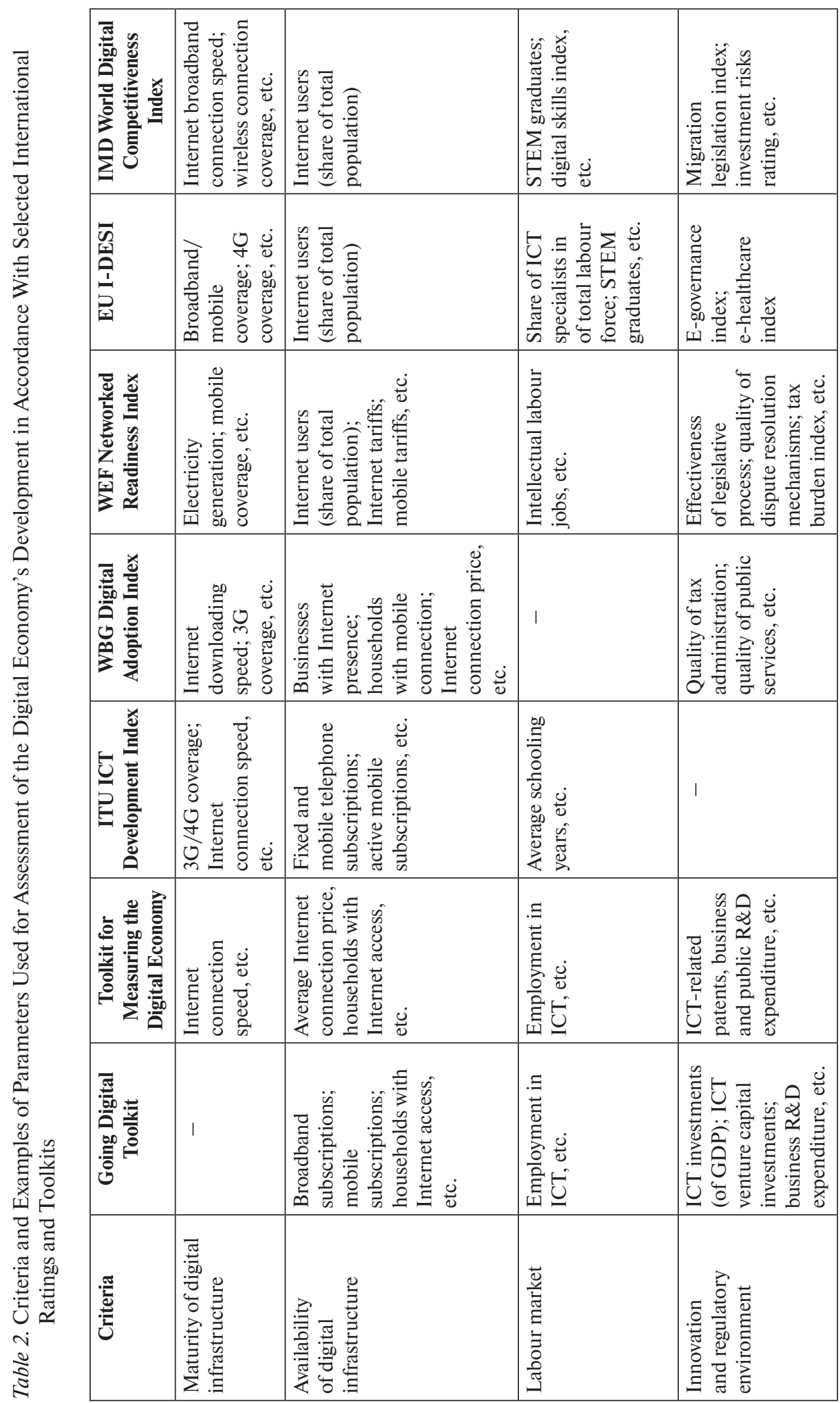




\begin{tabular}{|c|c|c|c|}
\hline 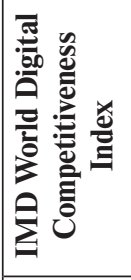 & 1 & 1 & 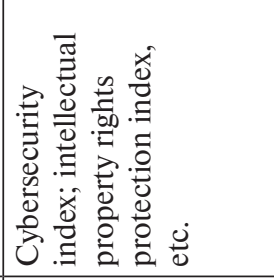 \\
\hline 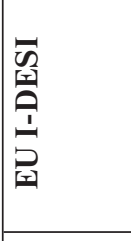 & 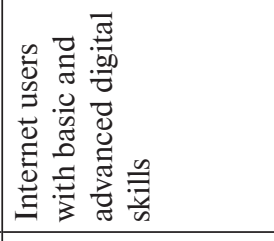 & 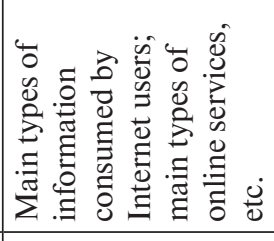 & 1 \\
\hline 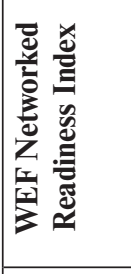 & 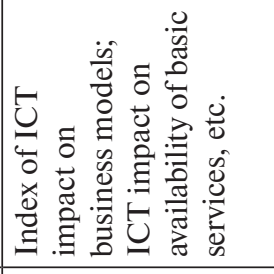 & 1 & 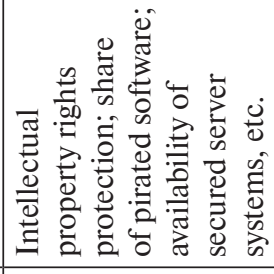 \\
\hline 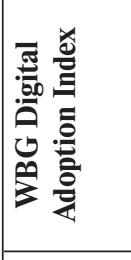 & 1 & 1 & 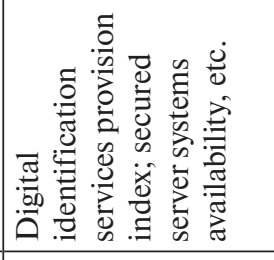 \\
\hline 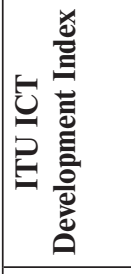 & 1 & 1 & 1 \\
\hline 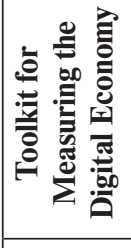 & 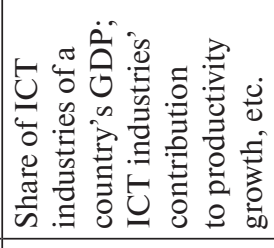 & 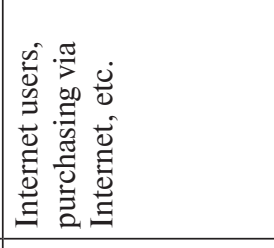 & 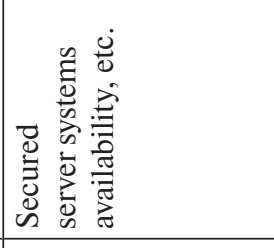 \\
\hline 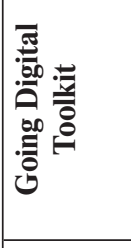 & 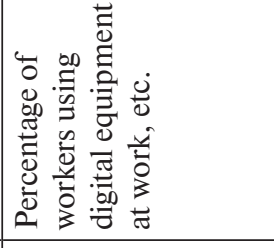 & 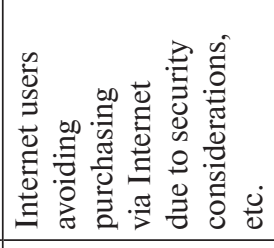 & 1 \\
\hline ن & 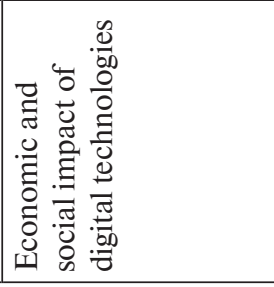 & 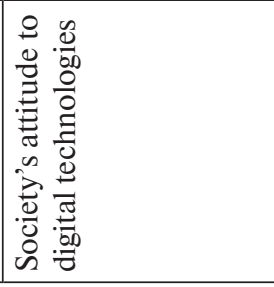 & 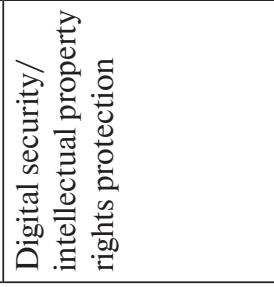 \\
\hline
\end{tabular}


Development (IMD) World Digital Competitiveness Ranking, can be used for analysis of the quality of regulatory and business environments and their impact on digital growth, as well as the influence of ICTs, on society.

The ratings and toolkits differ not only by designated sphere but also by sets of parameters and coefficients. To conduct research on the current condition of the digital economy in BRICS, all of these sources will be used. It should be noted that while the quality of digital infrastructure can be assessed with precision due to availability of statistics, assessments of the quality of regulatory environments, the societal impact of digital growth, society's perception of the ICTs, etc., should be treated with due consideration because of the methodological contradictions described earlier. These aspects require further comprehensive study.

The Toolkit for Measuring the Digital Economy and the Going Digital Toolkit, developed by the OECD in 2018-19, are based on quite similar sets of parameters. However, they are different in their methodological nuances.

The Toolkit for Measuring the Digital Economy [G20 Argentine Presidency, 2018] was introduced during Argentina's presidency of the Group of 20 (G20) in 2018. The toolkit includes 36 indicators divided into four groups. The Going Digital Toolkit ${ }^{2}$ was presented in March 2019 [OECD, 2019c]. In this case, 33 indicators were organized into seven groups (Table 3).

The indicators on which the above-mentioned toolkits are based demonstrate methodological differences arising from the original purpose of each instrument. The Toolkit for Measuring the Digital Economy was developed to "compile core, standardized and comparable indicators about the digital economy" [G20 Argentine Presidency, 2018, p. 4] to facilitate further nationwide assessment. The Going Digital Toolkit's purpose was to "increase an understanding of the drivers of digital transformation, ... [it offers] a whole-of-economy and society perspective on key digital trends, impacts and issues that require co-ordinated policy action" [OECD, 2019c, p. 3]. Thus, the first toolkit's objective is to gather and compile data on digital development; the objective of the second is to identify global digital trends to facilitate the decisionmaking process.

It should be noted that despite the sophisticated methodologies used by the instruments in question, there are number of problems associated with the availability of comparable data for all countries in all categories. In this case, further comparison of BRICS, G20 and OECD countries is limited to spheres for which data is sufficient.

Comparison of average results of measurement based on two given methodologies shows largely the same results in both cases (Fig. 2, 3). The BRICS countries generally lag in terms of the maturity of physical digital infrastructure (access speed, number of active users and households with Internet access). However, the BRICS countries demonstrate equal or even higher results than other G20 countries and OECD members in Internet access pricing. Russia outperforms its BRICS partners and many other in the world at large.

According to OECD estimations, innovative frameworks in BRICS countries are on the same level of development as in OECD and G20 states in some respects - numbers of STEM (science, technology, engineering and math) graduates, for instance (Table 4 and Fig. 2). BRICS and the OECD have achieved similar results in the total number of IT-related patents, with China as an absolute leader among the BRICS five (Table 5). At the same time, employment in ICT-related spheres in BRICS countries is lower than the G20/OECD average.

OECD toolkits are valuable sources of statistical data; however, they were not designed for ranking countries of the world in accordance with their current level of digital development. This function is exercised by international ratings that will be described next.

${ }^{2}$ The information that can be obtained by this tool is primarily relevant for OECD countries, however, for comparison, data is also provided for some non-OECD countries. 
Table 3. Selected Indicators From OECD Digital Development Toolkits

\begin{tabular}{|c|c|c|c|}
\hline \multicolumn{2}{|c|}{ Toolkit for Measuring the Digital Economy } & \multicolumn{2}{|r|}{ Going Digital Toolkit } \\
\hline Category & Selected Indicators $^{3}$ & Category & Selected Indicators \\
\hline Infrastructure & $\begin{array}{l}\text { Fixed and mobile broadband } \\
\text { subscriptions per } 100 \text { inhabitants; } \\
\text { fixed and mobile broadband prices; } \\
\text { households with a computer and } \\
\text { Internet access, etc. ( } 8 \text { ) }\end{array}$ & Access & $\begin{array}{l}\text { Fixed and mobile broadband } \\
\text { subscriptions per } 100 \text { inhabitants; } \\
\text { households with a computer and } \\
\text { Internet access; share of businesses } \\
\text { with broadband contracted speed of } \\
30 \text { Mbps or more, etc. (5) }\end{array}$ \\
\hline $\begin{array}{l}\text { Empowering } \\
\text { Society }\end{array}$ & $\begin{array}{l}\text { Individuals using the Internet to } \\
\text { interact with public authorities; } \\
\text { tertiary graduates in the natural } \\
\text { sciences, engineering and ICTs } \\
\text { (NSE \& ICT); individuals with } \\
\text { ICT skills, etc. (8) }\end{array}$ & Use & $\begin{array}{l}\text { Internet users as a share of } \\
\text { individuals; share of Internet users } \\
\text { who have purchased online in } \\
\text { the last } 12 \text { months; share of small } \\
\text { businesses making e-commerce } \\
\text { sales in the last } 12 \text { months, etc. (5) }\end{array}$ \\
\hline $\begin{array}{l}\text { Innovation and } \\
\text { Technology } \\
\text { Adaptation }\end{array}$ & $\begin{array}{l}\text { Patents in artificial intelligence } \\
\text { technologies; enterprises using } \\
\text { cloud computing services, etc. (8) }\end{array}$ & Innovation & $\begin{array}{l}\text { ICT investment as a percentage of } \\
\text { GDP; business R\&D expenditure } \\
\text { in information industries as a } \\
\text { percentage of GDP; patents in } \\
\text { ICT-related technologies, as a } \\
\text { percentage of total IP5 patent } \\
\text { families, etc. (5) }\end{array}$ \\
\hline \multirow{4}{*}{$\begin{array}{l}\text { Jobs and } \\
\text { Growth }\end{array}$} & \multirow[t]{4}{*}{$\begin{array}{l}\text { ICT goods as a percentage } \\
\text { of merchandise trade; ICT } \\
\text { contribution to labour productivity } \\
\text { growth, etc. (12) }\end{array}$} & Society & $\begin{array}{l}\text { ICT task-intensive jobs as a } \\
\text { percentage of total employment; } \\
\text { share in total employment by } \\
\text { digital-intensive sectors (5) }\end{array}$ \\
\hline & & Trust & $\begin{array}{l}\text { Percentage of individuals who live } \\
\text { in households with income in the } \\
\text { lowest quartile using the Internet; } \\
\text { women as a share of all people aged } \\
16-24 \text { who can programme, etc. } \\
\text { (5) }\end{array}$ \\
\hline & & \multirow{2}{*}{$\begin{array}{l}\text { Market } \\
\text { Openness }\end{array}$} & $\begin{array}{l}\text { Percentage of individuals not } \\
\text { buying online due to payment } \\
\text { security concerns, etc. (4) }\end{array}$ \\
\hline & & & $\begin{array}{l}\text { Share of businesses making } \\
\text { e-commerce sales that sell across } \\
\text { borders; Digital Services Trade } \\
\text { Restrictiveness Index, etc (4) }\end{array}$ \\
\hline
\end{tabular}

Sources: [G20 Argentine Presidency, 2018; OECD, 2019c].

${ }^{3}$ The number in brackets shows the total number of indicators used. 
Fixed broadband subscriptions per 100 inhabitants

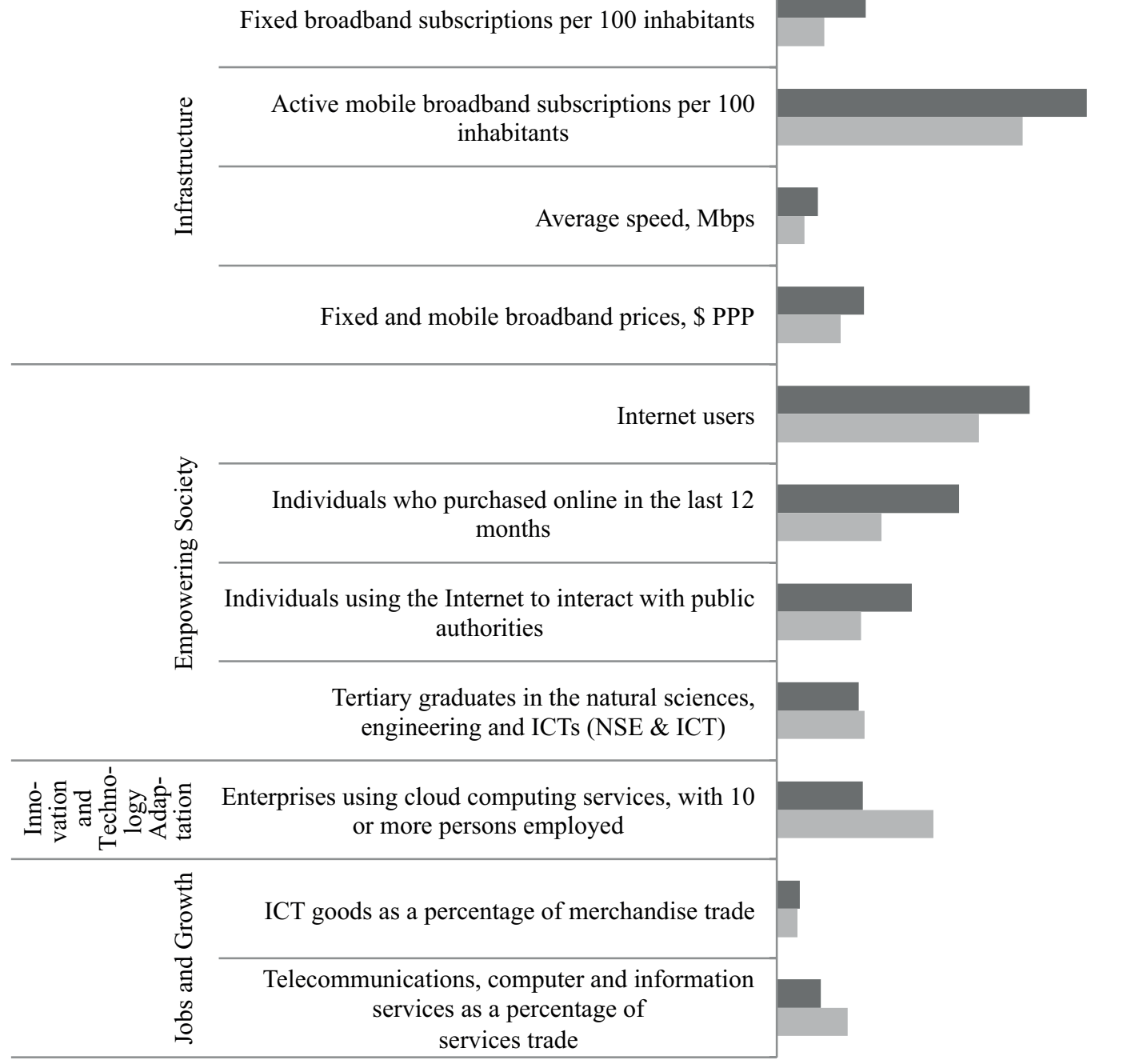

Fixed and mobile broadband prices, \$ PPP
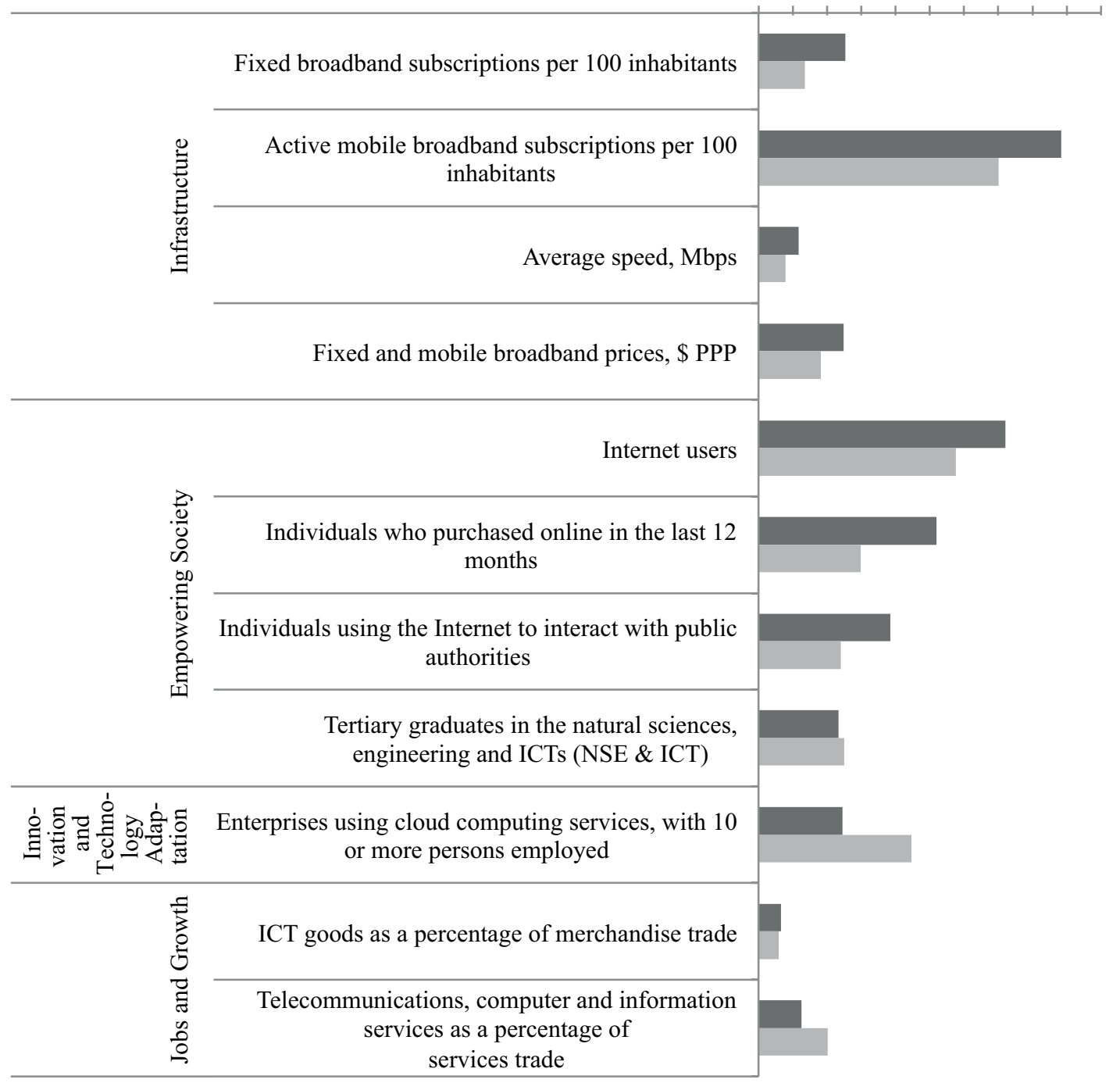

$\square$ G20 BRICS

Fig. 2. BRICS and G20 Country Averages According to the Toolkit for Measuring the Digital Economy Indicators

Source: [G20 Argentine Presidency, 2018]. 


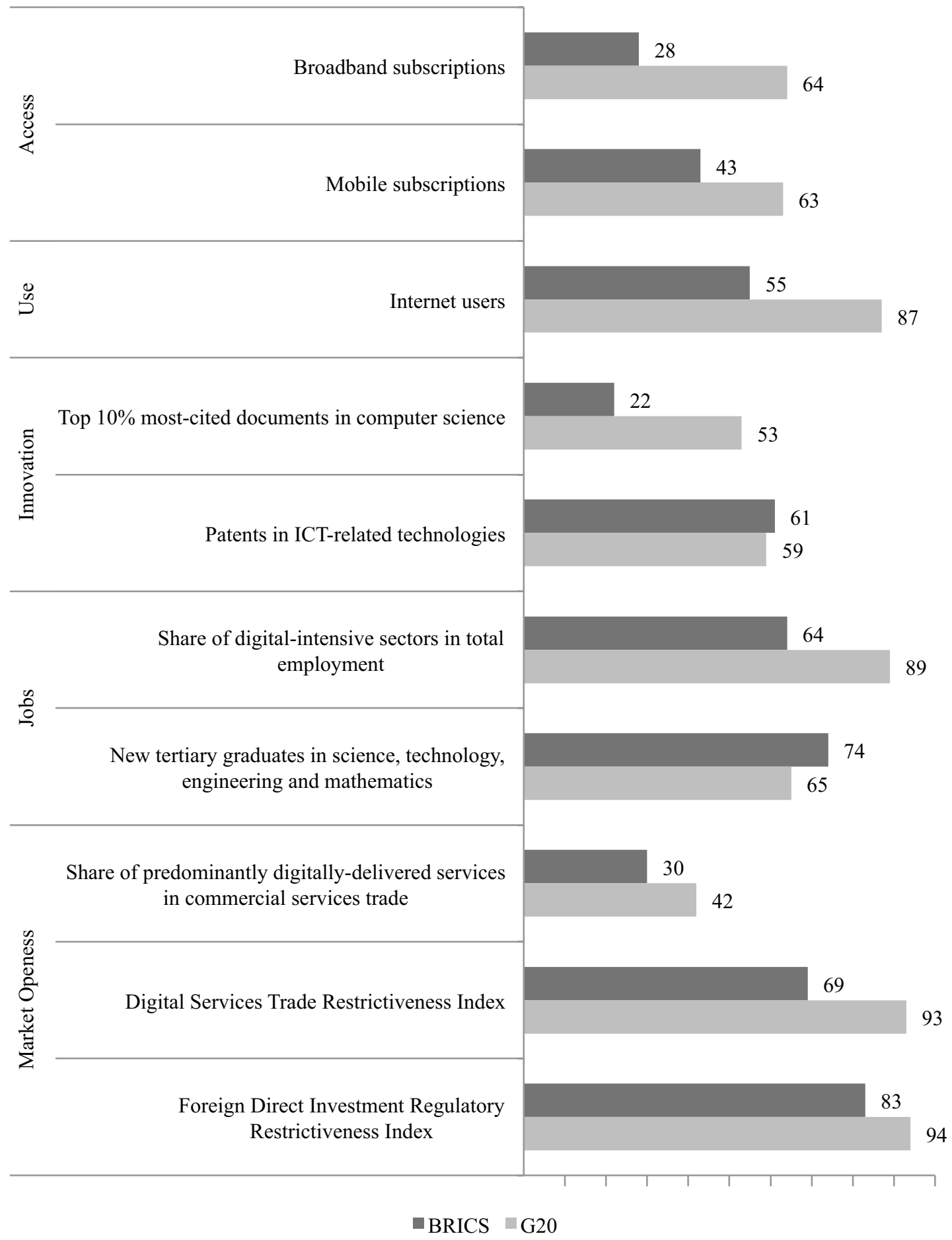

Fig. 3. BRICS and G20 Country Averages According to the OECD Going Digital Toolkit Source: [OECD, 2019c]. 
Table 4. Selected Indicators of Digital Development in the BRICS Countries Using the OECD Toolkit for Measuring the Digital Economy

\begin{tabular}{|c|c|c|c|c|c|c|}
\hline Category & Indicators & China & Brazil & South Africa & India & Russia \\
\hline \multirow{4}{*}{ 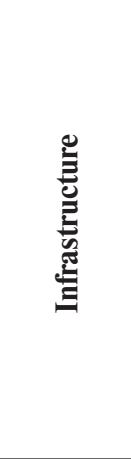 } & $\begin{array}{l}\text { Fixed broadband } \\
\text { subscriptions per } 100 \\
\text { inhabitants }\end{array}$ & 28.0 & 13.7 & 3.0 & 1.3 & 21.4 \\
\hline & $\begin{array}{l}\text { Active mobile } \\
\text { broadband } \\
\text { subscriptions per } 100 \\
\text { inhabitants }\end{array}$ & 83.6 & 90.2 & 70.0 & 25.8 & 80.8 \\
\hline & Average speed, Mbps & 7.6 & 6.8 & 6.7 & 6.5 & 11.8 \\
\hline & $\begin{array}{l}\text { Fixed and mobile } \\
\text { broadband prices, } \\
\text { \$PPP }\end{array}$ & 16.1 & 29.9 & 18.0 & 17.1 & 10.1 \\
\hline \multirow{4}{*}{ 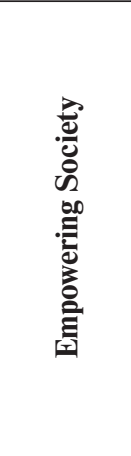 } & Internet users & 54.3 & 67.5 & 56.2 & 34.5 & 76.0 \\
\hline & $\begin{array}{l}\text { Individuals who } \\
\text { purchased online in } \\
\text { the last } 12 \text { months }\end{array}$ & $\mathrm{x}$ & 40.2 & $\mathrm{x}$ & $\mathrm{x}$ & 19.6 \\
\hline & $\begin{array}{l}\text { Individuals using the } \\
\text { Internet to interact } \\
\text { with public authorities }\end{array}$ & $\mathrm{x}$ & 24.0 & $\mathrm{x}$ & $\mathrm{x}$ & $\mathrm{x}$ \\
\hline & $\begin{array}{l}\text { Tertiary graduates in } \\
\text { the natural sciences, } \\
\text { engineering and ICTs } \\
\text { (NSE \& ICT) }\end{array}$ & $\mathrm{x}$ & 15.0 & $\mathrm{x}$ & 31.0 & 29.0 \\
\hline 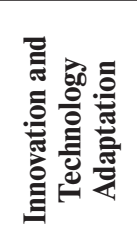 & $\begin{array}{l}\text { Enterprises using } \\
\text { cloud computing } \\
\text { services, with } 10 \\
\text { or more persons } \\
\text { employed }\end{array}$ & $\mathrm{x}$ & 44.6 & $\mathrm{x}$ & $\mathrm{x}$ & $\mathrm{x}$ \\
\hline \multirow{2}{*}{ 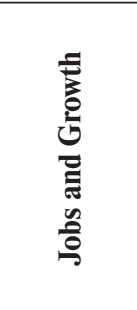 } & $\begin{array}{l}\text { ICT goods as a } \\
\text { percentage of } \\
\text { merchandise trade }\end{array}$ & 26.5 & 0.39 & 1.4 & 0.95 & 0.55 \\
\hline & $\begin{array}{l}\text { Telecommunications, } \\
\text { computer and } \\
\text { information services as } \\
\text { a percentage of } \\
\text { services trade }\end{array}$ & $\mathrm{x}$ & 10.0 & $\mathrm{x}$ & 36.6 & 14.2 \\
\hline
\end{tabular}

Source: [G20 Argentine Presidency, 2018]. 
Table 5. Indicators of the BRICS Countries Using the OECD Going Digital Toolkit

\begin{tabular}{|c|c|c|c|c|c|c|}
\hline Category & Indicators & Brazil & Russia & India & China & South Africa \\
\hline \multirow{2}{*}{ Access } & $\begin{array}{l}\text { Broadband } \\
\text { subscriptions }\end{array}$ & 29 & 46 & 3 & 57 & 6 \\
\hline & Mobile subscriptions & 55 & 50 & 16 & 51 & 43 \\
\hline Use & Internet users & 59 & 77 & 30 & 55 & 55 \\
\hline \multirow[t]{2}{*}{ Innovation } & $\begin{array}{l}\text { Top } 10 \% \text { most- } \\
\text { cited documents in } \\
\text { computer science }\end{array}$ & 27 & 20 & 16 & 29 & 19 \\
\hline & $\begin{array}{l}\text { Patents in ICT-related } \\
\text { technologies }\end{array}$ & 18 & 80 & 70 & 104 & 31 \\
\hline \multirow[b]{2}{*}{ Jobs } & $\begin{array}{l}\text { Share of digital- } \\
\text { intensive sectors in } \\
\text { total employment }\end{array}$ & 75 & 76 & 43 & 50 & 75 \\
\hline & $\begin{array}{l}\text { New tertiary graduates } \\
\text { in science, technology, } \\
\text { engineering and } \\
\text { mathematics }\end{array}$ & 47 & 86 & 88 & $\mathrm{x}$ & $\mathrm{x}$ \\
\hline \multirow{3}{*}{$\begin{array}{l}\text { Market } \\
\text { Openness }\end{array}$} & $\begin{array}{l}\text { Share of } \\
\text { predominantly } \\
\text { digitally delivered } \\
\text { services in commercial } \\
\text { services trade }\end{array}$ & 21 & 42 & 36 & 24 & 27 \\
\hline & $\begin{array}{l}\text { Digital Services Trade } \\
\text { Restrictiveness Index }\end{array}$ & 67 & 72 & 76 & 56 & 72 \\
\hline & $\begin{array}{l}\text { Foreign Direct } \\
\text { Investment Regulatory } \\
\text { Restrictiveness Index }\end{array}$ & 91 & 82 & 79 & 69 & 95 \\
\hline
\end{tabular}

Source: [OECD, 2019c].

\section{ICT Development Index}

The ICT Development Index composed by the International Telecommunication Union (ITU) is a rich source of information on the progress of the digital economy's development. The rating is based on a set of indicators characterizing the maturity of digital technologies. The figures are presented annually in the "Measuring the Information Society" report. The rating includes 11 indicators divided into three groups [ITU, 2018].

According to ITU's assessment, in 2017 the BRICS countries showed results corresponding with the global average with the exception of India, which ranked 134th out of 176. The leading countries on the list are Iceland, Korea, Switzerland, Denmark and the United Kingdom (Table 6).

\section{Digital Adoption Index}

The World Bank Group's Digital Adoption Index (DAI), in addition to providing data on the maturity of digital infrastructure in terms of accessibility and quality, implies assessment of the efficiency of national customs services, the quality of online services, and so on. This rating 


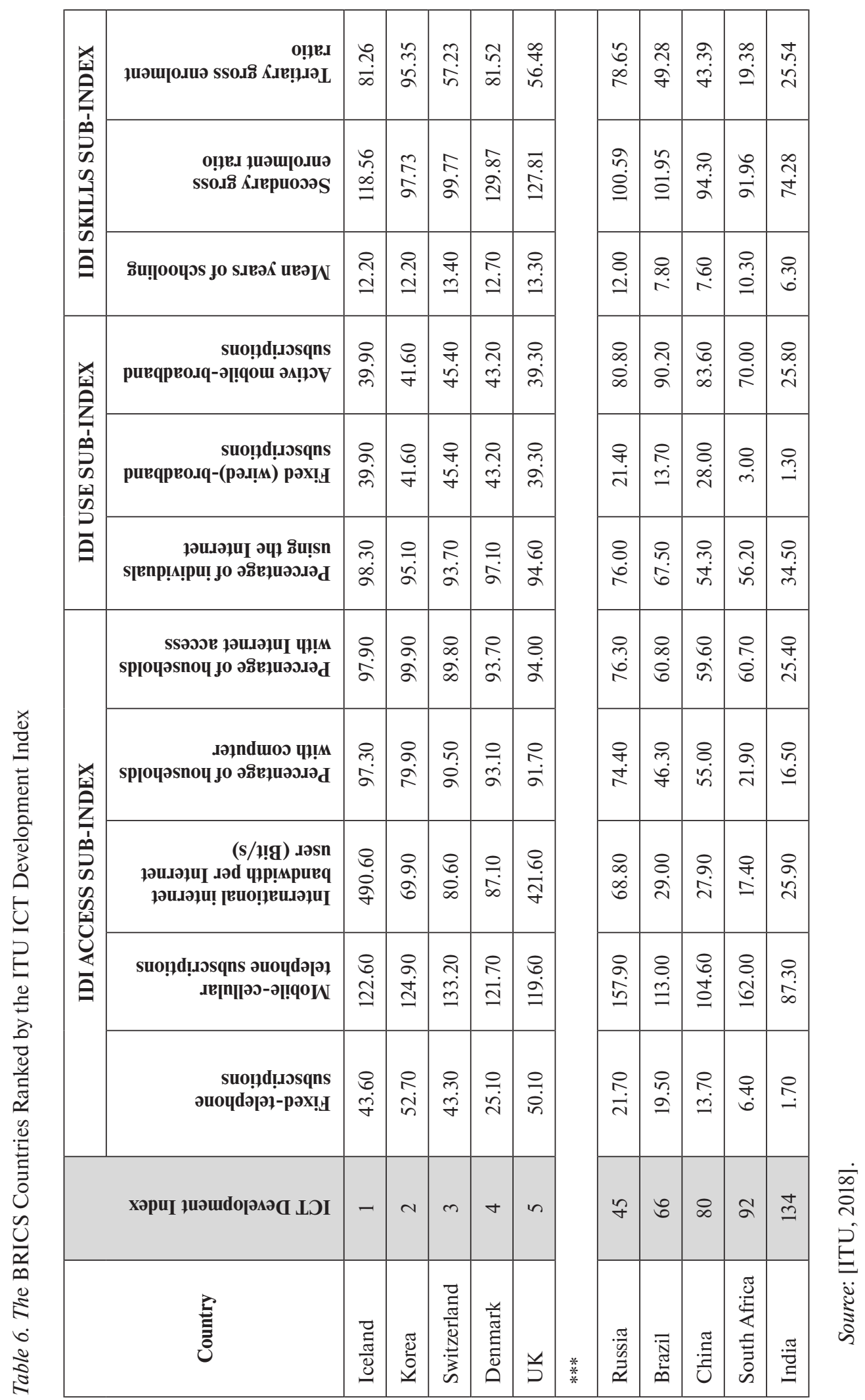


is subdivided into three components - DAI People, focused on usage of ICTs by citizens, DAI Business and DAI Government which focus on the implementation of digital technologies by business and government, respectively [WBG, 2016].

Based on DAI data, BRICS countries lag behind the group of leaders - Singapore, Luxembourg, Austria, Korea and Malta. A considerable gap exists in the overall level of ICT penetration into the daily activities of citizens. However, the BRICS five achieved much in the implementation of ICTs in public services. (Fig. 4 and Table 7).

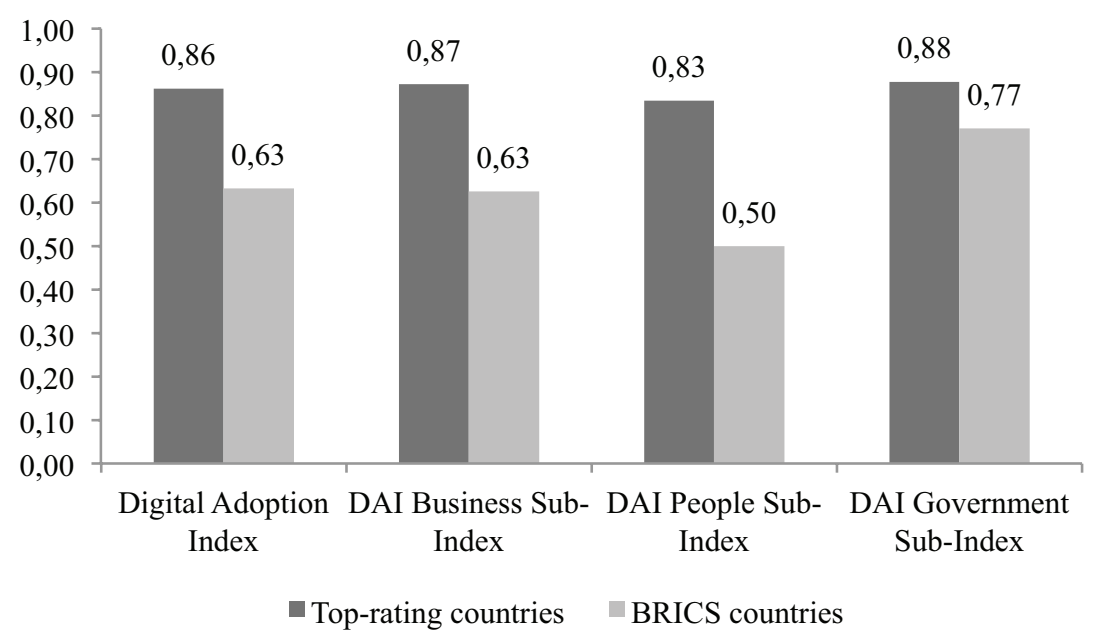

Fig. 4. BRICS Average Results in the WBG Digital Adoption Index Compared With the Top-Five Average

Source: [WBG, 2016].

Table 7. Digital Development Indicators of the BRICS Countries in the WBG Digital Adoption Index

\begin{tabular}{|l|c|c|c|c|}
\hline & $\begin{array}{c}\text { Digital Adoption } \\
\text { Index }\end{array}$ & $\begin{array}{c}\text { DAI Business Sub- } \\
\text { Index }\end{array}$ & $\begin{array}{c}\text { DAI People } \\
\text { Sub-Index }\end{array}$ & $\begin{array}{c}\text { DAI Government Sub- } \\
\text { Index }\end{array}$ \\
\hline Brazil & 0.68 & 0.68 & 0.55 & 0.82 \\
\hline Russia & 0.74 & 0.71 & 0.70 & 0.82 \\
\hline India & 0.51 & 0.50 & 0.23 & 0.80 \\
\hline China & 0.59 & 0.55 & 0.52 & 0.69 \\
\hline South Africa & 0.64 & 0.69 & 0.50 & 0.73 \\
\hline
\end{tabular}

Source: [WBG, 2016].

\section{Networked Readiness Index}

The Networked Readiness Index developed by the World Economic Forum includes a set of 53 indicators combined in 10 groups and four sub-indexes [Baller, Dutta, Lanvin, 2016]. In 2016, Brazil, Russia, India, China and South Africa ranked 72th, 41th, 91th, 59th and 65th out of 139 , respectively. The lowest scores were given to BRICS countries in the environment 
sub-index, while in other spheres results are close to the average (Table 8). The group of leading countries includes Singapore, Finland, Sweden, Norway and the United States.

Table 8. The BRICS Countries in the WEF Networked Readiness Index

\begin{tabular}{|c|c|c|c|c|c|c|c|c|c|c|c|}
\hline \multirow[t]{2}{*}{ Countries } & \multirow[b]{2}{*}{ 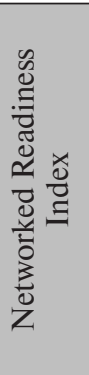 } & \multicolumn{2}{|c|}{ Environment } & \multicolumn{3}{|c|}{ Readiness } & \multicolumn{3}{|c|}{ Usage } & \multicolumn{2}{|c|}{ Impact } \\
\hline & & 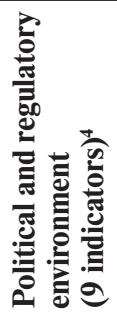 & 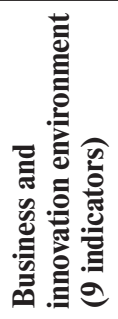 & 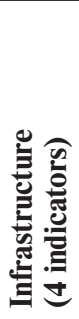 & 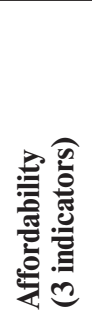 & 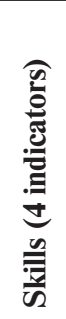 & 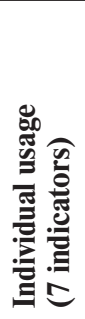 & 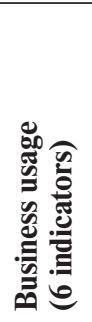 & 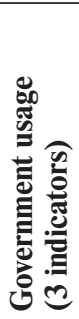 & 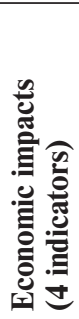 & 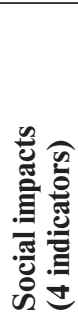 \\
\hline Singapore & 1 & 5.9 & 6.0 & 6.6 & 5.3 & 6.5 & 6.4 & 5.4 & 6.3 & 5.9 & 6.2 \\
\hline Finland & 2 & 5.8 & 5.4 & 7.0 & 6.4 & 6.5 & 6.6 & 5.8 & 5.0 & 6.1 & 5.5 \\
\hline Sweden & 3 & 5.5 & 5.2 & 7.0 & 6.2 & 5.8 & 6.7 & 6.0 & 5.0 & 6.1 & 5.6 \\
\hline Norway & 4 & 5.7 & 5.4 & 7.0 & 6.1 & 6.0 & 6.7 & 5.5 & 5.2 & 5.4 & 5.2 \\
\hline U.S. & 5 & 5.2 & 5.5 & 7.0 & 6.4 & 5.8 & 6.2 & 5.9 & 5.4 & 5.8 & 5.7 \\
\hline \multicolumn{12}{|c|}{$* * *$} \\
\hline Russia & 41 & 3.6 & 4.5 & 4.7 & 6.6 & 5.4 & 5.3 & 3.6 & 4.4 & 3.7 & 4.6 \\
\hline China & 59 & 3.9 & 3.8 & 3.3 & 5.5 & 5.4 & 3.9 & 3.9 & 4.6 & 3.8 & 4.7 \\
\hline South Africa & 65 & 5.0 & 4.3 & 4.9 & 5.2 & 4.4 & 3.9 & 4.2 & 3.3 & 3.4 & 3.3 \\
\hline Brazil & 72 & 3.4 & 3.4 & 4.5 & 6.2 & 4.5 & 4.8 & 3.7 & 3.6 & 3.1 & 3.9 \\
\hline India & 91 & 3.7 & 3.7 & 2.6 & 6.6 & 4.1 & 2.1 & 3.6 & 4.1 & 3.1 & 4.1 \\
\hline
\end{tabular}

Source: [Baller, Dutta, Lanvin, 2016].

\section{World Digital Competitiveness Ranking}

The World Digital Competitiveness Ranking by the International Institute for Management Development uses 50 parameters combined into three groups. These groups are subdivided into three subcategories (sub-factors) (Table 9).

According to the World Digital Competitiveness Rating, the BRICS countries perform quite modestly. China ranks the highest among the BRICS five -30 th out of 63 . The lowest score goes to Brazil at 57th. Russia, India and South Africa rank 40th, 48th and 49th, respectively.

\section{International Digital Economy and Society Index (I-DESI)}

The International Digital Economy and Society Index (I-DESI) developed by the European Union allows comparison of the digital economy development of member and selected non-member countries. ${ }^{5}$ The rating uses five groups of parameters (Table 10).

\footnotetext{
${ }^{4}$ The number in brackets shows the total number of indicators.

${ }^{5}$ Brazil, Russia and China are the only BRICS countries that were included into the rating.
} 
Table 9. The BRICS Countries in the IMD International Digital Competitiveness Index

\begin{tabular}{|l|l|c|c|c|c|c|}
\hline \multirow{5}{*}{} & Ranking (from 1 to 63) & Brazil & Russia & India & China & $\begin{array}{c}\text { South } \\
\text { Africa }\end{array}$ \\
\cline { 3 - 7 } & & 57 & 40 & 48 & 30 & 49 \\
\hline \multirow{4}{*}{ Knowledge } & Talent & 61 & 40 & 43 & 18 & 54 \\
\cline { 2 - 7 } & Training \& Education & 57 & 12 & 59 & 46 & 54 \\
\cline { 2 - 7 } & Scientific concentration & 54 & 23 & 26 & 21 & 47 \\
\hline \multirow{3}{*}{$\begin{array}{l}\text { Future } \\
\text { Readiness }\end{array}$} & Regulatory framework & 59 & 38 & 56 & 26 & 53 \\
\cline { 2 - 7 } & Capital & 56 & 58 & 3 & 30 & 27 \\
\cline { 2 - 7 } & Technological framework & 47 & 38 & 62 & 40 & 58 \\
\cline { 2 - 7 } & Bdaptive attitudes & 38 & 39 & 54 & 23 & 56 \\
\cline { 2 - 7 } & Business agility & 52 & 62 & 33 & 19 & 38 \\
\hline
\end{tabular}

Source: [IMD, 2018].

BRICS countries perform quite poorly in comparison with the countries of the Union. A significant lag exists in the usage of ICTs by business. Relatively high results were achieved by the BRICS countries in usage of digital technologies for the provision of public services.

Table 10. Brazil, Russia and China in the EU I-DESI Ranking

\begin{tabular}{|l|c|c|c|c|c|c|}
\hline & Brazil & Russia & China & EU Top 4 & EU average & EU Bottom 4 \\
\hline Connectivity & 39.5 & 38.9 & 45.9 & 75.2 & 62.9 & 52.2 \\
\hline Human Capital & 39.2 & 64.1 & 40.5 & 74.7 & 58.0 & 43.7 \\
\hline $\begin{array}{l}\text { Use of Internet } \\
\text { Services by } \\
\text { Citizens }\end{array}$ & 33.8 & 48.7 & 45.3 & 78.5 & 59.7 & 44.4 \\
\hline $\begin{array}{l}\text { Integration } \\
\text { of Digital } \\
\begin{array}{l}\text { Technology by } \\
\text { Business }\end{array}\end{array}$ & 27.8 & 29.8 & 40.7 & 72.8 & 51.3 & 32.3 \\
\hline $\begin{array}{l}\text { Digital Public } \\
\text { Services }\end{array}$ & 62.4 & 56.8 & 58.6 & 84.7 & 63.1 & 41.1 \\
\hline
\end{tabular}

Source: [EU, 2018].

Available data demonstrates that the BRICS countries struggle with the issue of accessibility of digital infrastructure in terms of the availability of digital devices allowing usage of digital services and information in digital format. For instance, in India and Brazil the number of households with a personal computer is two-to-four times lower than in the group of leading countries. The BRICS countries lag behind in the number of broadband connections by 10-20\% [ITU, 2018]. In this context the case of Russia is an exception - not only is its digital 
infrastructure as mature as that of the global leaders, but it is also one of the most affordable [G20 Argentine Presidency, 2018]. The BRICS countries partly compensate for the insufficiency of backbone digital infrastructure with a high number of users of mobile devices and services [ITU, 2018].

The business environment in BRICS countries is characterized by a low overall penetration by ICTs. This can be defined both by insufficiency of infrastructure and immaturity of regulatory and innovative frameworks [see IMD, 2018; Baller et al., 2016]. China is an exception here - it is not only ahead of its BRICS partners in the total number of registered IP5related patents, but also ranks very high from a global perspective [OECD, 2019b]. The current spread of digital skills in BRICS countries is a reason for optimism - indicators characterizing the readiness of a nation's education system for the challenges of the digital era in BRICS are very close to the world's best [see EU, 2018; ITU, 2018]. Further, IT-related jobs are in high demand in BRICS, as shown by the total number of STEM-graduates in BRICS countries [OECD, 2019c].

\section{BRICS' National Digital Agenda}

Development of the digital economy is considered a main pillar of strategic development planning in all five BRICS countries. Moreover, the digital agenda is well represented in the concluding documents and decisions of BRICS summits.

\section{Brazil}

The Strategy of Social and Economic Development of Brazil includes the development and promotion of ICTs as a main factor of economic growth. The Strategy's priorities in this sphere are facilitation of competition in ICT, mitigation of the negative impact of a deepening digital divide, and reduction of the costs to implement digital solutions in manufacturing and daily activities [Government of Brazil, 2018a].

The Operating National Strategy of Scientific, Innovative and Technological Development of Brazil for 2016-22 is aimed at facilitating the implementation of ICTs in business, monetization of ICT-related research, and promotion of basic studies in ICTs [Ibid., 2016]. These priorities are further developed in the Strategy of Digital Transformation of Brazil, adopted in 2018. In addition to the above-mentioned goals, this document adds improvement of infrastructure, increase in the total number of households with Internet access, safety in the digital environment, promotion of digital education, and deepening of regional and global partnerships in the digital sphere to the list of priorities [Ibid., 2018b].

Development of the ICT sphere is also considered a security priority along with aerospace and nuclear energy, according to the National Security Strategy of Brazil [Ibid., 2012].

Along with national programmes and strategies, Brazil actively promotes the digital agenda in international fora as a member of the Southern Common Market (MERCOSUR) and the Economic Commission for Latin America and the Caribbean (ECLAC). In 2017 Brazil, as chair of MERCUSOR, supported the establishment of a working group to coordinate a common stance on Internet governance, common regulations of licensing of digital products, and the conduct of digital trade in goods and services [Valente, 2017]. Together with other Latin American countries, Brazil supported the introduction of the Digital Agenda for Latin America Until 2020, focused on sustainability issues and equality in the digital era [ECLAC, 2018]. 


\section{Russia}

Development of ICTs and the digital economy are included in the list of Russia's strategic priorities. The Digital Economy of the Russian Federation programme, promulgated in December 2018, is aimed at increasing government support for digital development, improvement of digital infrastructure in terms of better access of households and businesses, and promotion of national software production [Government of the Russian Federation, 2018].

Russia's Concept of Social and Economic Strategic Development Until 2020 considers development of ICTs to be the most efficient instrument to support economic development and the national economy's competitiveness. In this context, the main priorities are the establishment of a single information space, nationwide access to broadband infrastructure, and better availability of digital services for the general population [Ibid., 2008].

The Doctrine of National Security of the Russian Federation considers digitization to be a pillar of national policy in this sphere. Amended in December 2016, the Doctrine views ICTs as an essential attribute of all kinds of personal activities, and views the usage of ICTs as a factor of the country's strategic development. In addition, information technologies are regarded as a fundamental element in the realization of Russia's security priorities [Ibid., 2016].

Russia actively promotes national digital priorities in international fora. Russia has a representative to the UN Internet Governance Forum's Multistakeholder Advisory Group (MAG) [IGF, n. d.]; a permanent representative of Russia is accredited in the Internet Corporation for Assigned Names and Numbers (ICANN) - the most influential nongovernmental body within the system of Internet governance [ICANN, n. d.]. Russia also participates in the activities of the Regional Commonwealth in the Field of Communications (RCC) [Government of the Russian Federation, n. d.], members of which are generally former Soviet republics along with several observer states and representatives of key international organizations.

\section{India}

The Government of India considers digital development to be a key driver of the country's economic growth. The Action Plan for 2017-18 and 2019-20 includes three main directions for its activities: digital infrastructure, software production, and the broadening of economic opportunities by means of wider implementation of ICTs.

The priorities under the pillars of the Action Plan are: improvement of broadband access to infrastructure to increase coverage of households in rural and remote areas; promotion of "net neutrality;" building-up of digital skills in the country's general population to facilitate an overall increase of digital literacy; development of electronic industry to satisfy local demand and increase export revenue; improvement of legislation on cybersecurity-related issues and data protection; further increase of quality of digital public services [Government of India, 2017]. A special national programme was established in February 2019 to support local software producers [PMIndia, 2019]. The Digital India programme initiated in 2015 with the support of Prime Minister Narendra Modi is aimed at promotion of the above-mentioned priorities [Ibid., 2018].

India considers the safety of information infrastructure and technological self-sufficiency of the digital component of the country's defence industry to be among the main pillars of its security policy [Government of India, 2018]. 
As a regional leader, India successfully incorporates its national digital priorities in the agenda of the South Asian Association for Regional Cooperation (SAARC). In 2004, a designated working group on the promotion of cooperation in the IT sphere among members was established. The working group coordinates a joint stance on international tariffs, promotion of regional IT-infrastructure, building-up regional connectivity, exchange of best practices and expertise in IT-related issues and cybersecurity matters, among other things [SAARC, n. d.].

Along with the regional initiatives, India participates in discussion on issues of global Internet governance via its permanent representative to the MAG.

\section{China}

China considers the IT sphere to be a crucial component of national security policy, as underlined in the National Cybersecurity Strategy [Government of China, 2016a]. The Strategy sets out the following list of priorities in cybersecurity: protection of national sovereignty in cyberspace; the fight against cybercrimes; improvement of instruments of governance of cyberspace and; promotion of international cooperation on related matters.

The digital economy is among the priorities of the 13th Five Year plan [Ibid., 2016b]. The core priorities of China's digital policy are to: develop IT-infrastructure, including proliferation of optical and wireless networks; increase average Internet connection speed; develop disruptive technologies, namely the Internet of Things (IoT) and; cloud computing.

China actively engages in multilateral discussion on digital issues. China's representatives are accredited in MAG and ICAAN. As a leading decision maker in the Shanghai Cooperation Organisation (SCO), China promotes a cybersecurity agenda. In 2015, the SCO presented a draft multilateral convention on cybersecurity that demonstrated China's commitment to a multilateral decision-making process on matters of personal and national security in the digital age [Ibid., 2017].

\section{South Africa}

South Africa's National Development Plan - 2030 [Government of South Africa, 2012] focuses on the following priorities of digital development: promotion of infrastructure investment; support of local demand on digital goods; and employment of foreign expertise of key international organizations and bodies, namely the ITU.

As a complex subject, the digital agenda of South Africa was formed in 2016-17 when the national government presented a series of strategic documents. The above-mentioned priorities were enhanced with new directions for action put forward in the ICT Integrated Policy White Book [Ibid., 2016]. The National Digital Strategy [Ibid., 2017] also added a cybersecurity dimension, focusing on diversification of software and hardware markets.

South Africa promotes a digital agenda on multilateral basis. During its first presidency in the South African Development Community in 2008-09, the Protocol on Science, Technologies and Innovations was approved to facilitate cooperation among countries of the region on science and innovation, R\&D investments, removal of barriers to exchanges in technologies and expertise, etc., through the establishment of specialized mechanisms [SADC, 2008]. The agenda was further enhanced after the adoption of the Action Plan on Development of Regional IT-Infrastructure Until 2027 [Ibid., 2012]. The Plan focuses on issues of regional infrastructural connectivity within the broader context of the establishment of a single information space. 
South Africa supports discussion and decision-making processes on ICT-related issues as a member of the African Union (AU). The country's national priorities correlate with the AU's agenda on digital development: during the meeting on ICT-cooperation matters between the $\mathrm{AU}$ and the EU, Minister of Communications, Telecommunications and Postal Services Stella Ndabeni-Abrahams declared the development of an affordable ICT-infrastructure and a system of occupational retraining as top priorities [Government of South Africa, 2018].

Against the backdrop of differences in the relative maturity of their digital economies, the BRICS countries nevertheless pursue the same set of priorities. The main direction for action is the development of digital infrastructure and the promotion of access of the general population, businesses and governmental bodies to digital services. The BRICS five pay great attention to the issues of digital transformation of the labour market and proliferation of digital skills. ICT development is also considered a pillar of national security policy in all five countries. The above-mentioned priorities are actively promoted by means of BRICS institutions in the form of joint initiatives and concrete decisions.

\section{BRICS Digital Agenda}

At present, BRICS' digital agenda encompasses a limited range of issues. This can be explained by the relatively short period of time that has passed since the very first decision was made.

At first, issues related to digital development were discussed as a part of a wider agenda of scientific cooperation, and later, in discussions on development of ICTs at large. BRICS countries started to make concrete decisions in 2018; since 2015 and until Johannesburg (2018), only meetings of BRICS ministers responsible for ICT development took place.

BRICS first addressed the issues of digital development during the Russian presidency in 2015, when the first meeting of communications ministers was held in Moscow. The meeting concluded with an action plan [BRICS, 2015b] and a decision to establish an ad hoc working group to discuss and formulate decisions on digital development for further approval by BRICS ministers [Ibid., 2015a].

During South Africa's second BRICS presidency in 2018, members agreed to launch the Partnership for the Fourth Industrial Revolution (PartNIR). The new platform was designed to facilitate exchange of expertise and best practices in the promotion of digital industries and to create impetuses for economic growth [Ibid., 2018].

A relatively high level of compliance of the countries with the decisions on digital development made during BRICS summits proves the demand for further cooperation in this sphere.

Since 2011, 38 decisions on digital issues have been made by the BRICS five. The most significant contribution was made in 2015 when 17 commitments were adopted. The Chinese BRICS presidency in 2017 resulted in 12 concrete decisions on the digital agenda. Compliance has reached $94 \%$ on average (Table 11 ).

\section{Recommendations for Russia's Third BRICS Presidency}

Development of the digital economy is a pending issue for each BRICS country. However, Brazil, Russia, India, China and South Africa are at different stages of digital development. Taking these factors into account, BRICS as an institution could nevertheless form a firm ground for making concrete strategic decisions in this sphere.

One promising direction for cooperation among the BRICS countries is expansion of exchanges of best practices, information and expertise on matters relating to digital development. 
Table 11. The Number of BRICS Commitments on Digital Issues and the Level of Compliance With Commitments Selected for Monitoring

\begin{tabular}{|l|c|c|c|c|}
\hline & Ufa 2015 & Goa 2016 & Xiamen 2017 & Johannesburg 2018 \\
\hline $\begin{array}{l}\text { Number of } \\
\text { Commitments }\end{array}$ & 17 & 3 & 12 & 3 \\
\hline $\begin{array}{l}\text { Level of } \\
\text { Compliance With } \\
\begin{array}{l}\text { Commitments } \\
\text { Selected for } \\
\text { Monitoring }\end{array}\end{array}$ & $90 \%$ & $90 \%$ & $100 \%$ & - \\
\hline
\end{tabular}

Source: [author, based on analysis by the Center for International Institutions Research (CIIR) RANEPA, Moscow].

BRICS has not yet established a designated mechanism for regular data sharing on indicators of digital development, proposed and operational projects of the partner countries in this sphere, best available practices of facilitation of digital development, issues and nuances of regulation of digital production, or digital trade. Once established, this mechanism could be based on an existing platform (i.e., ICT ministers meetings, the BRICS Working Group on ICT Cooperation) which would allow expansion of the scope of expert groundwork to facilitate the resolution of current issues relating to digital development, including adaptation of statistical services to the needs of assessment of the digital economy itself and the contribution of ICT-related industries to GDP creation. Introduction of new indicators and improvement of existing metrics would increase the quality and effectiveness of strategic planning to bridge the growing digital divide and cope with emerging vulnerabilities.

The BRICS countries could achieve much in conceptualizing common standards of production of digital goods and services. A universal standard has not yet been introduced. BRICS' proposal may become the first of a kind and thus set the path for future initiatives. Moreover, a universal digital standard would greatly increase the value of intra-BRICS trade and facilitate investment cooperation.

The third promising direction is joint promotion of BRICS' common stance on cybersecurity matters. All five members of BRICS have declared the fight against cybercrime and emerging digital threats to be a strategic priority; many of them have a hand in decision-making on matters of Internet governance. China has already presented its view on key elements of an international security system in the cyber sphere. In 2020 Russia, as president of BRICS and member of the SCO, could facilitate the conversion of China's proposed initiative on the SCO platform into a BRICS-led concept, and thus support its promotion within the UN system.

\section{References}

Baller S., Dutta S., Lanvin B. (eds) (2016) The Global Information Technology Report 2016: Innovating in the Digital Economy. World Economic Forum/INSEAD Insight Report. Available at: http://www3.weforum.org/ docs/GITR2016/WEF_GITR_Full_Report.pdf (accessed 19 July 2019).

Bilbao-Osorio B., Dutta S., Lanvin B. (eds) (2013) The Global Information Technology Report 2013: Growth and Jobs in a Hyperconnected World. World Economic Forum/INSEAD Insight Report. Available at: http:// www3.weforum.org/docs/WEF_GITR_Report_2013.pdf (accessed 19 July 2019).

\footnotetext{
${ }^{6}$ See RANEPA [n. d.] for a complete list of commitments made by the BRICS countries.
} 
BRICS (2015a). Communiqué of BRICS Ministers of Communications on the Outcomes of the Meeting "Expansion of Cooperation in the Field of Communications and ICTs." Moscow, 23 October. Available at: https://www.ranepa.ru/images/media/brics/ruspresidency2/Communique_BRICS_ICT_ministers_eng.pdf (accessed 19 July 2019).

BRICS (2015b). BRICS Science, Technology and Innovation Work Plan 2015-2018. Available at: https:// www.ranepa.ru/images/media/brics/ruspresidency2/Work_Plan_STI_28Oct2015_(2).pdf (accessed 19 July 2019).

BRICS (2018). Declaration of the 4th BRICS Communication Ministers Meeting. KwaZulu-Natal, 15 September. Available at: https://www.ranepa.ru/images/media/brics/sapresidency2/BRICS_ICT_2018.pdf (accessed 19 July 2019).

Bukht R., Heeks R. (2018) Defining, Conceptualising and Measuring the Digital Economy. International Organisations Research Journal, vol. 13, no 2, pp. 143-172. Available at: http://doi.org/10.17323/1996-7845-201802-07. (in Russian)

Dutta D., Mia I. (eds) (2011) The Global Information Technology Report 2010-2011: Transformations 2.0. World Economic Forum/INSEAD. Available at: http://reports.weforum.org/wp-content/pdf/gitr-2011/wefgitr-2010-2011.pdf (accessed 19 July 2019).

Economic Commission for Latin America and the Caribbean (ECLAC) (2018). Digital Agenda for Latin America and the Caribbean (eLAC2020). Sixth Ministerial Conference on the Information Society in Latin America and the Caribbean. Available at: https://conferenciaelac.cepal.org/6/sites/elac2020/files/cmsi.6_digital_agenda-en-23_april.pdf (accessed 19 July 2019).

European Commission (2019). Final Report of the High-Level Expert Group on the Impact of the Digital Transformation on EU Labour Markets. 8 April. Available at: https://ec.europa.eu/digital-single-market/en/news/ final-report-high-level-expert-group-impact-digital-transformation-eu-labour-markets (accessed 19 July 2019).

European Union (EU) (2018). International Digital Economy and Society Index 2018. SMART 2017/0052. Available at: https://ec.europa.eu/newsroom/dae/document.cfm?doc_id=54991 (accessed 19 July 2019).

G20 Argentine Presidency (2018). Organisation for Economic Co-operation and Development (OECD) Toolkit for Measuring the Digital Economy: Draft Version. Available at: http://www.oecd.org/g20/summits/ buenos-aires/G20-Toolkit-for-measuring-digital-economy.pdf (accessed 19 July 2019).

Government of Brazil (2012). Defence White Paper. Available at: https://www.defesa.gov.br/arquivos/ estado_e_defesa/livro_branco/lbdn_2013_ing_net.pdf (accessed 19 July 2019) (in Portuguese).

Government of Brazil (2016). National Science, Technology and Innovation Strategy 2016-2022. Ministry of Science, Technology, Innovation and Communication. Available at: http://www.mctic.gov.br/mctic/export/ sites/institucional/publicacao/ciencia/ENCTI/MCTIC_ENCTI_2016-2022_210x240mm_14.03.2017.pdf (accessed 19 July 2019) (in Portuguese).

Government of Brazil (2018a). National Strategy for Economic and Social Development. Ministry of Planning, Development and Management. Available at: http://www.planejamento.gov.br/assuntos/planeja/endes/ estrategia-nacional/view (accessed 19 July 2019) (in Portuguese).

Government of Brazil (2018b). Brazilian Digital Transformation Strategy. E-Digital. Available at http://www. mctic.gov.br/mctic/export/sites/institucional/estrategiadigital.pdf (accessed 19 July 2019) (in Portuguese).

Government of China (2016a). Full Text of the National Cyberspace Security Strategy. Available at: http:// www.cac.gov.cn/2016-12/27/c_1120195926.htm (accessed 19 July 2019) (in Chinese).

Government of China (2016b). The 13th Five-Year Plan for Economic and Social Development of the People's Republic of China 2016-2020. Available at: http://en.ndrc.gov.cn/newsrelease/201612/ P020161207645765233498.pdf (accessed 19 July 2019).

Government of China (2017). International Strategy of Cooperation on Cyberspace. Available at: http://www. chinadaily.com.cn/kindle/2017-03/02/content_28409210.htm (accessed 19 July 2019).

Government of India (2017). India Three Year Action Agenda 2017-18 to 2019-20. Available at: https://niti. gov.in/writereaddata/files/coop/India_ActionAgenda.pdf (accessed 19 July 2019). 
Government of India (2018). Draft Defence Production Policy 2018. Available at: https://ddpmod.gov.in/sites/ default/files/Draft\%20Defence\%20Production\%20Policy\%202018\%20-\%20for\%20website.pdf (accessed 19 July 2019).

Government the Russian Federation (n. d.). Regional Commonwealth in the Field of Communications. Ministry of Digital Development, Communications and Mass Media of the Russian Federation. Available at: https:// digital.gov.ru/en/events/list/?directions=292 (accessed 10 September 2019).

Government of the Russian Federation (2008). The Concept of Long-Term Socioeconomic Development of the Russian Federation for the Period Until 2020.Available at: http://gov.garant.ru/SESSION/PILOT/main. htm (accessed 19 July 2019) (in Russian).

Government of the Russian Federation (2016). Doctrine of Information Security of the Russian Federation. Ministry of Foreign Affairs of the Russian Federation. Available at: http://www.mid.ru/en/foreign_policy/official_documents/-/asset_publisher/CptICkB6BZ29/content/id/2563163 (accessed 19 July 2019).

Government of the Russian Federation (2018). Passport of the National Programme "Digital Economy of the Russian Federation". Available at: http://static.government.ru/media/files/urKHm0gTPPnzJlaKw3M5cNLo6gczMkPF.pdf (accessed 19 July 2019) (in Russian).

Government of South Africa (2012). National Development Plan 2030: Our Future: Make It Work. Department of the Presidency. Available at: https://www.gov.za/sites/default/files/gcis_document/201409/ndp2030-our-future-make-it-workr.pdf (accessed 19 July 2019).

Government of South Africa (2016). National Integrated ICT Policy White Paper. Department of Telecommunications and Postal Services. Available at: https://www.dtps.gov.za/images/phocagallery/Popular_Topic Pictures/National_Integrated_ICT_Policy_White.pdf (accessed 19 July 2019).

Government of South Africa (2017). Digital Society South Africa: South Africa's National E-Strategy: Towards a Thriving and Inclusive Digital Future. Government Gazette, vol. 629, no 41242. Available at: https://www.dtps. gov.za/images/phocagallery/Popular_Topic_Pictures/National-e-strategy.pdf (accessed 19 July 2019).

Government of South Africa (2018). Minister Ndabeni-Abrahams Participates in High-Level Dialogue on Taking AU-EU Cooperation to the Digital Age. Media Release, 18 December. Available at: https://www.dtps. gov.za/index.php?option $=$ com_content $\&$ view $=$ article \&id $=782$ :minister-ndabeni-abrahams-participates-inhigh-level-dialogue-on-taking-au-eu-cooperation-to-the-digital-age\&catid=13\&Itemid=138 (accessed $10 \mathrm{Sep}$ tember 2019).

Group of 20 (G20) (2016). G20 Blueprint on Innovative Growth. Available at: https://www.ranepa.ru/images/ media/g20/2016Hangzhou/G20\%20Blueprint\%20on\%20Innovative\%20Growth.pdf (accessed 19 July 2019).

Hansen L., Nissenbaum H. (2009) Digital Disaster, Cyber Security, and the Copenhagen School. International Studies Quarterly, vol. 53, no 4, pp. 1155-1175. Available at: https://doi.org/10.1111/j.1468-2478.2009.00572.x.

Institute for Management Development (IMD) (2018). IMD World Digital Competitiveness Ranking 2018. Available at: https://www.imd.org/globalassets/wcc/docs/imd_world_digital_competitiveness_ranking_2018. pdf (accessed 19 July 2019).

Internet Corporation for Assigned Names and Numbers (ICANN) (n. d.). Government Advisory Committee. Available at: https://gac.icann.org (accessed 10 September 2019).

Internet Governance Forum (IGF) (n. d.). About MAG. Available at: https://www.intgovforum.org/multilingual/content/about-mag (accessed 10 September 2019).

International Monetary Fund (IMF) (2018). Measuring the Digital Economy. IMF Staff Report. Available at: https://www.imf.org/ /media/Files/Publications/PP/2018/022818MeasuringDigitalEconomy.ashx (accessed 19 July 2019).

International Telecommunication Union (ITU) (2017). ICT Facts and Figures 2017. Available at: https://www. itu.int/en/ITU-D/Statistics/Documents/facts/ICTFactsFigures2017.pdf (accessed 19 July 2019).

International Telecommunication Union (ITU) (2018). Measuring the Information Society Report, vol. 2: ICT Country Profiles. Available at: https://www.itu.int/en/ITU-D/Statistics/Documents/publications/misr2018/ MISR-2018-Vol-2-E.pdf (accessed 19 July 2019). 
Organisation for Economic Co-operation and Development (OECD) (2001). Understanding the Digital Divide. OECD Digital Economic Paper No 49. Available at: https://doi.org/10.1787/236405667766 (accessed 19 July 2019).

Organisation for Economic Co-operation and Development (OECD) (2008). The Seoul Declaration for the Future of the Internet Economy. OECD Digital Economic Paper No 147. Available at: https://doi. org/10.1787/230445718605 (accessed 19 July 2019).

Organisation for Economic Co-operation and Development (OECD) (2013). Measuring the Internet Economy. OECD Digital Economic Paper No 226. Available at: https://doi.org/10.1787/5k43gjg6r8jf-en (accessed 19 July 2019).

Organisation for Economic Co-operation and Development (OECD) (2014). Measuring the Digital Economy: A New Perspective. Available at: https://doi.org/10.1787/9789264221796-en (accessed 19 July 2019).

Organisation for Economic Co-operation and Development (OECD) (2017). OECD Digital Economy Outlook 2017. Available at: https://dx.doi.org/10.1787/9789264276284-en (accessed 19 July 2019).

Organisation for Economic Co-operation and Development (OECD) (2018). Bridging the Rural Digital Divide. OECD Digital Economy Papers No 265. Available at: https://doi.org/10.1787/852bd3b9-en (accessed 19 July 2019).

Organisation for Economic Co-operation and Development (OECD) (2019a). Vectors of Digital Transformation. OECD Digital Economy Papers No 273. Available at: https://doi.org/10.1787/5ade2bba-en (accessed 19 July 2019).

Organisation for Economic Co-operation and Development (OECD) (2019b). Measuring the Digital Transformation: A Roadmap for the Future. Available at: https://doi.org/10.1787/9789264311992-en (accessed 19 July 2019).

Organisation for Economic Co-operation and Development (OECD) (2019c). Going Digital: Shaping Policies, Improving Lives. Available at: https://doi.org/10.1787/9789264312012-en (accessed 19 July 2019).

PMIndia (2018). PM's Address During His Interaction with the Beneficiaries of Digital India. 15 June. Available at: https://www.pmindia.gov.in/en/news_updates/pms-address-during-his-interaction-with-the-beneficiaries-of-digital-india/?comment=disable (accessed 10 September 2019).

PMIndia (2019). Cabinet Approves National Policy on Software Products - 2019. 28 February. Available at: https://www.pmindia.gov.in/en/news_updates/cabinet-approves-national-policy-on-software-products2019/?comment=disable (accessed 10 September 2019).

Russian Presidential Academy of National Economy and Public Administration (RANEPA) (n. d.). Commitments Adopted at BRICS Summits. Available at: https://www.ranepa.ru/eng/ciir-ranepa/research-areas/ brics/commitments-adopted-at-brics-summits/commitments-adopted-at-brics-summits (accessed $10 \mathrm{Sep}$ tember 2019).

South Asian Association for Regional Cooperation (SAARC) (n. d.). Information and Poverty Alleviation. Available at: http://saarc-sec.org/areas_of_cooperation/area_detail/information-and-poverty-alleviation/ click-for-details_9 (accessed 10 September 2019).

South African Development Community (SADC) (2008). Protocol on Science, Technology and Innovation. Available at: https://www.sadc.int/files/3013/5292/8367/Protocol_on_Science_Technology_and_Innovation2008.pdf (accessed 19 July 2019).

South African Development Community (SADC) (2012). Regional Infrastructure Development Master Plan. Available at: https://www.sadc.int/files/9413/5293/3532/Regional_Infrastructure_Development_Master_ Plan_ICT_Sector_Plan.pdf (accessed 19 July 2019).

Tapscott D. (2015) The Digital Economy, Anniversary Edition: Rethinking Promise and Peril in the Age of Networked Intelligence. New York: McGraw-Hill.

United Nations Conference of Trade and Development (UNCTAD) (2017a). Information Economy Report 2017: Digitalization, Trade and Development. Available at: https://unctad.org/en/PublicationsLibrary/ier2017_ en.pdf (accessed 19 July 2019). 
United Nations Conference of Trade and Development (UNCTAD) (2017b). World Investment Report 2017: Investment and the Digital Economy. Available at: https://unctad.org/en/PublicationsLibrary/wir2017_en.pdf (accessed 19 July 2019).

United States Trade Representative (2018). 2018 Fact Sheet: Key Barriers to Digital Trade. Available at: https:// ustr.gov/about-us/policy-offices/press-office/fact-sheets/2018/march/2018-fact-sheet-key-barriers-digital (accessed 19 July 2019).

Valente J. (2017) Mercosur to Create Group to Deal With Digital Economy. Agência Brasil, 12 December. Available at: http://agenciabrasil.ebc.com.br/es/internacional/noticia/2017-12/mercosur-creara-grupo-paratratar-de-economia-digital (accessed 19 July 2019). (in Portuguese)

Watanabe C. et al. (2018) Measuring DGP in the Digital Economy: Increasing Dependence on Uncaptured GDP. Technological Forecasting \& Social Change, vol. 137, pp. 226-40. Available at: https://doi.org/10.1016/j. techfore.2018.07.053 (accessed 19 July 2019).

World Bank Group (WBG) (2016). Digital Adoption Index (DAI): Measuring the Global Spread of Digital Technologies. Background Note: Digital Dividends. Available at: http://pubdocs.worldbank.org/ en/587221475074960682/WDR16-BP-DAI-methodology.pdf (accessed 19 July 2019).

Zhang L., Chen S. (2019) China's Digital Economy: Opportunities and Risks. IMF Working Paper no 19/16. Available at: https://www.imf.org/en/Publications/WP/Issues/2019/01/17/Chinas-Digital-Economy-Opportunities-and-Risks-46459 (accessed 19 July 2019). 